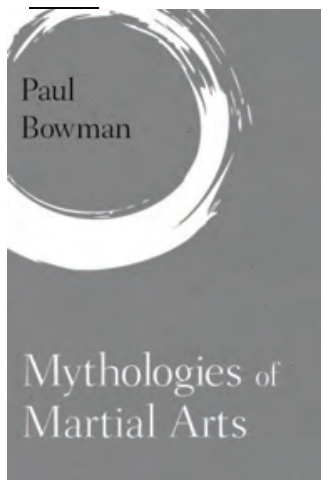

\title{
Paul Bowman,
}

Mythologies of Martial Arts (Martial Arts Studies, 2), London/New York: Rowman and Littlefield, 2017, xxiii + 186 p. ISBN: 9781786601926 (pbk.)

Reviewed by Sixt Wetzler, Deutsches Klingenmuseum Solingen (s.wetzler@solingen.de)

«Die Mythosforschung ist zum Berührungspunkt mannigfaltiger Zweige der Gelehrsamkeit geworden: [...] Historiker und Soziologe, Literaturwissenschaftler und Grammatiker, Germanist und Romanist, Keltenforscher und Slawist, sie alle reden darüber, je unter sich. Auch vor Logikern und Psychologen, vor Metaphysikern und Epistemologen ist die Mythologie nicht sicher - um von den Gästen ganz zu schweigen, den Theosophen, den heutigen Astrologen oder den Szientisten. Schließlich ist noch die Psychoanalyse hinzugekommen, uns beizubringen, dass der Mythos ein Tagtraum der Menschheit sei [...]. Als sich zu guter Letzt der arme Anthropologe und Volkskundler dem Fest anschloss, war kaum ein Krümel für ihn übrig. Wenn ich einen Eindruck von Chaos und Konfusion vermittelt, wenn ich angesichts der unglaublichen Mythologie-Debatte und all dem Staub, den sie aufgewirbelt hat, Beklommenheitsgefühle hervorgerufen habe, so habe ich erreicht was ich wollte.» ${ }^{1}$

Thus wrote famous ethnologist Bronislaw Malinowski in 1926. Had he known that, almost one hundred years later, a branch of academia had developed that called itself "martial arts studies" - he would hardly have been surprised to hear that it, too, has its own take on mythology, which comes in the form of a short monograph. "Mythologies of Martial Arts", the second title in the new Martial Arts Studies book series at Rowman \& Littlefield, has been written by Paul Bowman, professor of cultural studies at Cardiff University, UK. To those interested not only in HEMA research, but in martial arts studies in general, Bowman is of course well known: as the organizer of the Martial Arts Studies conferences at Cardiff University, editor of the online Martial Arts Studies journal, founder of the aforementioned book series and director of the Martial Arts Studies research network, he is one of the key figures and active motors in the formation of this new field.

"Mythologies of Martial Arts" takes up several of the strands Bowman laid out in his last book "Martial Arts Studies: Disrupting Disciplinary Boundaries". As the title implies, it deals with the ideological narratives that surround, permeate, and define martial arts, and the ways they are practiced, perceived, and culturally dealt with. While Bowman's theoretical approach is deeply rooted in (mostly French) postmodernism, and indebted to Hegelian and Marxist thought, his ideological impetus is that of the Anglo-American

\footnotetext{
1 Malinowski, Bronislaw, 'Die Rolle des Mythos im Leben', in Malinowski, Bronislaw, Schriften in vier Bänden, 4/2, ed. by Kramer, Fritz (Syndikat: Frankfurt a. M. 1986; orig. 1926), p. 141.
} 
cultural studies. The methodological differences between these cultural studies and their German and French counterparts, and their practical consequences, have to be understood to fully appreciate Bowman's book: Continental Kulturwissenschaften (and similarly the disciplines of medieval and early modern history, of social anthropology, etc.) explicitly forbid themselves to morally judge what they are researching, and try to analyse, understand and describe neutrally (no matter how and if this might be truly possible). Cultural studies, on the other hand, were from their outset designed as political projects; they do not only want to understand the world, but also want to change it. ${ }^{2}$ Bowman is an exponent of the latter branch, and he will not shy away from conclusions und judgements that, e.g., a Swiss researcher might well harbour personally, but not put forth in academic writing. To Bowman, all mythology is on the verge of creating hierarchies of power, power that can and often will be abused, and result in injustice. Consequently, he perceives the eradication of mythology as an act of liberation (p. 94), especially where it comes to myths of authenticity, origin, and lineage (chapters 5 and 6). Uncommon as such statements (in themselves ideological) might be for readers from a different academic tradition, they do not diminish the accuracy and worth of the book's observations and interpretations. And these are excellent.

As he has himself pointed out continuously throughout his writings and lectures, Bowman is horrified of anything fixed, of the definition of the fluid, of static truths. He perceives culture(s), the martial arts therein, and its/their narrations of martial arts as network of meanings, attributions, and "supplements", each of which does not exist by and of itself, but is merely constituted by and helps itself constituting the other cultural condensations in this network. Referring to Stuart Hall, Bowman thus calls for a "conjunctural analysis" which understands any given phenomenon within its contextual dependencies and temporal fluidity - a perspective that, even if the terminologies might be different, might come natural to many of us. He applies the principle of the conjunctural analysis with great success on his subject, the popular martial arts discourses of the 20th and 21 st century. His angle is never straightforward, but (maybe exactly because of that) his results are even more convincing. The predominant questions in many martial arts discussions, be they among practitioners or academics, are: "what is?" and "what was?" The questions raised (and often quite satisfyingly answered) in the book are much more: "how do/did they imagine it to be?", "how do/did they tell others and are/were themselves told to imagine it to be?", and most of all "why do/did they want to imagine it to be that way? ${ }^{\text {?" }}$ Guided by these questions, Bowman discusses the status of Asian martial arts in the West, matters of cultural exchange and assumption, of ethnicity

${ }^{2}$ For a further discussion of these differences in regards to martial arts studies, see: Wetzler, Sixt, 'Martial Arts Studies as Kulturwissenschaft: a possible theoretical framework', Martial Arts Studies Journal 1 (2015), pp. 20-33. For an in-depth discussion of the two closely related disciplines, see: Musner, Lutz, 'Kulturwissenschaften und Cultural Studies: Zwei ungleiche Geschwister?', KulturPoetik 1.2 (2001), pp. 261-271

3 Of course, "they" could be exchanged with "we". 
and orientalism; the notion of qi in Western and Eastern discourses; authenticity and lineage; changing aesthetics in combative movement in action cinema; discourses of gender; the ping-pong of "mythological" narratives between East and West; and also the "mythological" undercurrents in martial arts studies themselves.

However, Bowman's "addiction" to the notion of instability and fluidity might also be the reason for what I perceive to be the main weak point of the book: being called "Mythologies of the Martial Arts", it lacks a theoretical discussion of the terms "myth" and "mythology" (often used interchangeably, which seems also the case in this book). This is problematic insofar, as both terms have been inflated to such a degree and used in so many different contexts, that it is nowadays impossible to know what someone speaks of when he uses either of them - the introduction quote from Malinowski describes the chaos aptly, and if anything, the situation has gotten worse in the last hundred years. Bowman starts his text with a reference to Roland Barthes. This is no wonder, given his affinity to the French thinkers of the 20th century. Barthes' understanding of the myth as condensed ideology fits neatly into Bowman's discourse analysis, and is made good use of here. However, in other parts, the book shifts to much more old fashioned notion of myth as the opposite of logos, without explicitly stating it: In the line of Stanley Henning's work, which aims to "debunk" the popular Chinese martial arts histories, myth is here a synonym for "historical lie". The book would have benefited from a short introduction into the possible meanings of the term myth, and a clearer awareness which of these meanings it is referring to at which point. Such a categorization - explicitly not supposed to a final definition, and thus well-fitting for Bowman's approach - has been given by Jan and Aleida Assmann, ${ }^{4}$ and already made fertile for martial arts studies in an article edited by Bowman himself. ${ }^{5}$

The second point of critique is of much less importance, but might be a lot harder to swallow for readers with a HEMA background: When Bowman writes martial arts, he means "Asian martial arts" in $95 \%$ of the cases. Often, he would list "wrestling, boxing, and martial arts" besides each other, thus juxtaposing Western and Eastern traditions. In this respect, his unwillingness to define what martial arts are (though well grounded) pose a problem - intuitively, Bowman has already decided that martial arts "are from the East". This notion is historically not true, as martial arts can be found almost anytime and everywhere. And even if understood in terms of the attitudes of popular culture (that, for a long time, might indeed have separated European fencing, boxing, and wrestling from the Asian styles), it is no longer true in the 21st century: After the MMA watershed, one can doubt that martial arts are still first and foremost Asian (or "marker of Asian-ness").

\footnotetext{
4 Assmann, Jan and Aleida, 'Mythos', in Handbuch religionswissenschaftlicher Grundbegriffe IV: Kultbild-Rolle, ed. by Cancik-Lindemaier, Hildegard, Cancik, Hubert, and Gladigow, Burkhard (Stuttgart: Kohlhammer, 1998), pp. 179-200.

5 Wetzler, Sixt, 'Myths of the Martial Arts', JOMEC Journal 5 (2014), available at: http://goo.gl/VP8OLA The article touches on several points also discussed in Bowman's book.
} 
Today, MMA rules supreme, and is felt and regarded as a Western or Global phenomenon; it is as much boxing, as it is muay thai, as much jiu jitsu as it is wrestling, as much sambo as judo (speaking, absolutely in line with Bowman, not about sambo's history as a direct offspring of judo, but about its perceived Russian-ness). MMA is as much US-American, Brazilian, and Russian as it is Japanese or Thai (and remarkably nonChinese, by the way). The iconic figure of the MMA is no longer the samurai, nor the Shaolin monk, but (thanks to the movie "300") the Spartan warrior, and the MMA-movie "Warrior" is in no need of any Asian characters or allusions.

Thirdly, in contrast to many HEMA researchers, Bowman seems less interested in the transmission and execution of martial arts techniques themselves than in the narratives being told about them. This is no shortcoming in itself; but at several points in the book (for example in the discussion of taiji principles, p. 165), one gets the impression that the author is at risk of falling himself into the "mythological trap", rephrasing common ideas what martial arts will do with a body.

Nevertheless: "Mythologies of Martial Arts" is a treasure hoard of thought and new ideas, and an ammunition belt (if one needs that) for any discussion of the self-stylization of martial arts. The book must be most highly recommended. The term "inspiring" is used inflationary, but here, I use it with full intention. While reading the book, every second or third page there was a moment when I would have liked to call the author (or anyone from my martial arts studies colleagues) to discuss what I had just read. This is not supposed to mean that I would agree with everything written there: For example, one wants to ask if the rather negative view on myth should not be balanced with the productive capacity of myths, and with what Blumenberg called "Arbeit am Mythos" (work on myth). Also, the scholar of European martial arts tradition feels compelled to point out how well known Asian styles were already around 1900 in the West, and that techniques of kicking (described, by Bowman, as purely Asian) were beautifully illustrated in a German "kickboxing manual" from 1863. ${ }^{6}$ But even at the points where the reader disagrees, his engagement with the book does not come to a standstill; Bowman's very personal, often humorous and enjoyable style of writing positively invites disagreement, and seems to look forward to the discussions it may catalyze.

The fact that Bowman is oriented more towards Asian than European martial arts leaves the HEMA researcher with countless opportunities for studies on the basis of this book; research that goes beyond the "Faktengeschichte" (history of facts, dates, and techniques) which is so common to HEMA studies. The text can at once be a toolbox and a mirror for any research into historical HEMA practice, modern HEMA training, or (para)academic HEMA studies themselves.

6 Happel, Jakob, Die Boxkunst (Leipzig: Weber, 1863). Online: http://digital.ub.uniduesseldorf.de/ihd/content/titleinfo/2461557 (accessed 30. MAR 2017) 
And finally - and here, we can acknowledge and share the "ideological impetus" mentioned before - "Mythologies of Martial Arts" may call the HEMA scene to challenge their own mythologies: mythologies of the allegedly clear intentions behind the fight books, of the "authentic" resurrection of lost practices, and most of all of the ethnicized "art of our forefathers". 